\title{
Tooth Pulp: A Foundation for DNA Analysis
}

\section{Sunit Kumar Jurel*}

Assistant Professor, Faculty of Dental Sciences, Upgraded KGMC Lucknow, India

\section{Introduction}

During the last few years, DNA analysis methods are being applied to forensic cases. Also, forensic dental record comparison had been used for human identification in cases where destruction of bodily tissues or prolonged exposure to the environment had made other means of identification impractical, i.e. after fire exposure, aircraft inflammation or mass disasters. Teeth represent an excellent source of genomic DNA. The interest in using dental tissues as a DNA-source of individual identification falls within the particular character of resistance of this organ towards physical or chemical exterior aggressions. Because of their resistant nature to environmental assaults such as incineration, immersion, trauma, mutilation and decomposition, teeth represent an excellent source of DNA material. However, to identify someone through dental identification pre-death dental records are needed.

DNA is a molecule that builds genes, so the gene carries all genomic information that determines inherited characteristics. In the nucleus of all somatic cells in the body we find a double stranded structure of genomic DNA. Most of the cells inside the body contain organelles located in cytoplasm called mitochondria, and each mitochondria contains several mitochondrial DNA, mtDNA molecules.

A large number of mitochondria inside the cell increase the chance that, the mtDNA will stay preserved for a longer period. It is the only means of identification if there are a few generations' in-between people who's DNA are being compared.

A new method by the name of polymerase chain reaction or PCR, made using even very small amounts of DNA possible. Microanatomy of the tooth is very important for better procurement of the samples for DNA extraction, as are the methods used to obtain the sample. Pulp chamber, dentine powder, dentine-cement powder, cement powder, or adherent bone, periodontal fibers can be used as samples for isolation. The dentine-cement powder proved to be the best sample for isolation of either genomic or mitochondrial DNA, because the DNA in it remains well structured the longest and there is rarely any contamination with non-human DNA.

Methods currently used for obtaining samples for DNA isolation are: crushing the entire tooth, conventional endodontic access, vertical split, and horizontal section through the cervical root. The horizontal section through the cervical root seemed to be the best, as it permits rotary instrumentation of the inner dentine in root canals, and independent sampling of the cement, while conservation of the coronal morphology is very important for it can be used for morphological identification.

\section{Salivary DNA Recovered From Human Bite Marks}

The usual methods of analyzing human bite mark evidence involve systematic physical comparison of the pattern of the injury in lifesized photographs or tracings to models of the suspect's teeth. These comparisons are often subjective and depend on the experience and procedures used by the odontologist. Saliva is normally deposited on human skin during biting, sucking, licking and kissing, so the potential use of the DNA present in saliva stains on skin shows any role of the suspect in causing a given bite mark. Guidelines established by the American Board of Forensic Odontology (ABFO), 1995 for the collection of bite mark evidence advocate swabbing of the skin to collect saliva as part of the standard operating procedure. These swabs can be tested for amylase, a component of saliva. A positive test result confirms the presence of saliva and that the observed injury is in fact a bite mark.

Human saliva has been shown to be an excellent source of high molecular weight DNA. Saliva recovered from material at crime scenes (i.e. clothing, cigarette butts, postage stamps, envelope stamps) has been completely isolated, analyzed and compared to reference sources obtained from suspects.

\section{Conclusion}

The application of this DNA technology to forensic odontology cases is already a fact. DNA has been isolated and characterized from the dental pulp and saliva. This success provides a basis for reassociation of body parts that might not be otherwise possible because of decomposition. There is particular interest in mitochondrial DNA analysis because of its availability, especially in skeletal material remains and its successful characterization by PCR method. Using the DNA analysis' methods, DNA testing can be a powerful method of human identification.

*Corresponding author: Sunit Kumar Jurel, BDS, MDS, FAGE, FPFA, Faculty of Dental Sciences, Upgraded KGMC Lucknow, India, Tel: 09453604322 E-mail: dentistmj1110@yahoo.co.in

Received June 29, 2012; Accepted July 16, 2012; Published July 23, 2012

Citation: Sunit Kumar J (2012) Tooth Pulp: A Foundation for DNA Analysis. J Forensic Res 3:e111. doi:10.4172/2157-7145.1000e111

Copyright: $\odot 2012$ Sunit Kumar J. This is an open-access article distributed under the terms of the Creative Commons Attribution License, which permits unrestricted use, distribution, and reproduction in any medium, provided the original author and source are credited. 